\title{
Studies on Preparation, Sensory Evaluation and Cost Configuration of Potato (Solanum tuberosum) Flour Burfi
}

\author{
V.M. Ramteke*, V.G. Atkare and S.M. Khupse \\ Animal Husbandry and Dairy Science, College of Agriculture, Nagpur, India \\ *Corresponding author
}

\section{A B S T R A C T}

\begin{tabular}{|l|}
\hline K e y w o r d s \\
Cow milk, Potato flour, \\
Sensory evaluation, Cost \\
configuration
\end{tabular}

The research work on effect of different combinations of potato flour on sensory quality, proximate composition of cow milk burfi was conducted during 2017-2018 in the department of Animal Husbandry and Dairying at College of Agriculture, Nagpur. The different concentrations of potato flour were $\mathrm{T}_{1}(0 \%), \mathrm{T}_{2}(05 \%), \mathrm{T}_{3}(10 \%), \mathrm{T}_{4}(15 \%)$ and $\mathrm{T}_{5}$ (20\%). 30 per cent constant rate sugar was mixed in a khoa for preparation of burfi. The different levels of potato flour had a definite effect on improving the sensory quality like flavour, body and texture, colour and appearance also on overall acceptability of potato flour burfi. The score regarding the quality of cow milk burfi showed that the burfi prepared by utilizing cow milk khoa with 10 per cent potato flour had secured highest score (96.25 out of 100) and ranked as most acceptable product. Thus, it is inferred that a good quality cow milk burfi with utilizing potato flour can be prepared by $90 \%$ khoa + 10\% potato flour and 30 per cent sugar (Costing Rs.389.51).

\section{Introduction}

Milk has been used as an article of food since ancient times in India. Milk is an almost ideal food. It plays an important role in the diet. It is highly nutritious food which is rich in several nutrients, calcium, potassium, vitamins and proteins. People have been using cow milk since $6000,8000 \mathrm{BC}$ and $14^{\text {th }}$ century, it has gained immense popularity as one of the healthiest foods. Milk is high in protein, bone forming minerals, health giving vitamins and provides energy giving lactose and milk fat and essential fatty acid. India's milk production is 18.5 per cent of world milk production and now standing in first rank. Annual output about 163.6 million tonnes during 2016-17 and per capita availability in India is 351 grams per day by 2016-2017 (Anonymous, 2017). Out of total milk production 46 per cent is utilizes as fluids milk and remaining is convert into various milk products like paneer, rabri, basundi, cheese, ghee, ice-cream, channa, butter, yoghurt, dahi, etc. (Anonymous, 2015).

Among various milk sweets burfi is the most popular and nutritious khoa based indigenous sweet, prepared either from cow or buffalo milk or a combination thereof and sugar. It contains a considerable amount of milk solids and sugar is added in different proportions in different varieties. Indigenous milk product, burfi is capable of becoming such a novelty 
product in the world market. The manufacture of value added products like filled dairy products could be a better alternative. Now-aday local producers are using orange, mango, coconut, potato, etc. in preparation of Burfi.

Potato (Solanum tuberosum) is one of the most important staple food crops for human consumption, together with wheat, rice and corns. Currently more quantities of potatoes are processed into value added products to fulfill the need of fast food and convenience to food industry. Potato products found highly nutritious and these can easily supplemented to eradicate malnutrition among children. Potato has good food satisfaction value and must be consumed daily nutrition (Kaur and Kochhar, 2014). The energy intake from potatoes by an individual in developed and developing countries was 130 and 41 Kcal/day, respectively. Potatoes provide significant amounts of carbohydrates, potassium and ascorbic acid in the diet (Chandrasekara and Kumar, 2016). Potato flour is used in various value added products like soup, biscuits, breads, tikki, burfi, etc. Potato contains a number of nutrients and nutritional components that may play a role in health promotion and reducing the risk of chronic disease. Keeping in view the nutritive value of both, the above research had done.

\section{Materials and Methods}

\section{Materials}

The present study was conducted on the studies on preparation of burfi blended with potato flour at Department of Animal Husbandry and Dairy Science Section, College of Agriculture, Nagpur during the year 2017-2018.

Clean, fresh and whole cow milk was taken from Animal Husbandry and Dairy Science Section, College of Agriculture, Nagpur. Bulk milk sample was obtained in stainless steel container from the morning milking and the milk was filtered through the muslin cloth to avoid dirt and extraneous matter. The milk sample was analyzed for different milk constituent's viz., fat, protein, total solids, moisture and ash. The milk was standardized at 4 per cent fat by the addition of skim milk and cream was followed for adjustment of fat. Good quality ingredients like milk, sugar and potato were purchased from local market of Nagpur. Different equipments viz., Karahi, khunti, stainless steel trays, mixture grinder, gas burner, etc. were available in the department. Analytical reagent grade chemicals were used for the chemical analysis.

\section{Methods}

Treatments included different combinations like;

$\mathrm{T}_{1}=100$ parts of cow milk khoa +0 parts of potato flour i.e. (Control)

$\mathrm{T}_{2}=95$ parts of cow milk khoa +5 parts of potato flour

$\mathrm{T}_{3}=90$ parts of cow milk khoa +10 parts of potato flour

$\mathrm{T}_{4}=85$ parts of cow milk khoa +15 parts of potato flour

$\mathrm{T}_{5}=80$ parts of cow milk khoa +20 parts of potato flour

\section{Procedure for preparation of Burfi}

The cow milk was concentrated to a pasty consistency by evaporating in open pan on gentle fire. Sugar at the rate of 30 per cent was added and heated gently till pat formation. When the product started to leave the sides of karahi (within 5 to $8 \mathrm{~min}$ ), the potato flour was added @ rate of $0\left(\mathrm{~T}_{1}\right), 5\left(\mathrm{~T}_{2}\right), 10\left(\mathrm{~T}_{3}\right), 15\left(\mathrm{~T}_{4}\right)$ 
and $20\left(\mathrm{~T}_{5}\right)$ per cent and further heated on low flame till the product again started to leave the sides of karahi. The product taken off the flame and transferred into greasy tray and was allowed to cool and cut into a desirable size.

The observations were recorded for flavour, body and texture, colour and appearance and overall acceptability by using 100-point scale (Pal and Gupta, 1985) and on the basis of 9 point hedonic scale (Nelson and Trout, 1964). Statistical analysis was done as per method suggested by Snedecor and Cochran (1994).

\section{Results and Discussion}

\section{Sensory evaluation of potato flour burfi}

\section{Flavour}

The data from table 1 showed that the score obtained for flavour were 40.75, 41.00, 44.00, 40.50 and 40.25 for treatments 100:0 $\left(\mathrm{T}_{1}\right)$, 95:05 $\left(\mathrm{T}_{2}\right)$, 90:10 $\left(\mathrm{T}_{3}\right)$, 85:15 $\left(\mathrm{T}_{4}\right)$ and 80:20 $\left(\mathrm{T}_{5}\right)$ khoa to potato flour, respectively. The highest score (44 out of 45) was received by burfi prepared with 10 parts of potato flour $\left(\mathrm{T}_{3}\right)$. The lowest score (40.25 out of 50$)$ was received by burfi prepared with 20 parts of potato flour $\left(\mathrm{T}_{5}\right)$. Similar result was obtained by Meshram (2014), who reported that 7.5 per cent air potato flour $\left(\mathrm{T}_{4}\right)$ in burfi scored highest point 43.60 while 0 percent air potato flour $\left(T_{1}\right)$ was scored lowest point 35.80 for burfi.

\section{Body and texture}

The data from table 1 showed that the score obtained for body and texture were 30.75, $31.50,33.75,31.50$ and 30.25 for treatments 100:0 $\left(\mathrm{T}_{1}\right)$ 95:05 $\left(\mathrm{T}_{2}\right)$, 90:10 $\left(\mathrm{T}_{3}\right)$, 85:15 $\left(\mathrm{T}_{4}\right)$, and 80:20 $\left(\mathrm{T}_{5}\right)$ khoa to potato flour, respectively. The highest score (33.75 out of 35) for body and texture was obtained by burfi prepared with 10 parts of potato flour $\left(\mathrm{T}_{3}\right)$.
The lowest score (30.25 out of 35) was obtained by burfi prepared with 20 parts of potato flour $\left(\mathrm{T}_{5}\right)$. The present results are in agreement with the results obtained by Datarkar (2012), she reported that as the level of singhara flour increased, the score (32.23) for body and texture of burfi also increases up to certain limit.

\section{Colour and appearance}

The data from table 1 showed that the mean score for colour and appearance of burfi during various treatments 100:0 $\left(\mathrm{T}_{1}\right)$, 95:05 $\left(\mathrm{T}_{2}\right)$, 90:10 $\left(\mathrm{T}_{3}\right)$, 85:15 $\left(\mathrm{T}_{4}\right)$, and 80:20 $\left(\mathrm{T}_{5}\right)$ khoa to potato flour were $15.75,16.00,18.50$, 17.50 and 15.75 respectively.

The highest score (18.50 out of 20) for colour and appearance was obtained by burfi prepared with 10 parts of potato flour $\left(\mathrm{T}_{3}\right)$. The lowest score (15.75 out of 20) was obtained by burfi prepared with 20 parts of potato flour $\left(\mathrm{T}_{5}\right)$.

The results obtained in present study are in accordance with the results reported by Meshram (2014), he found that cow milk burfi prepared with $7.5\left(\mathrm{~T}_{4}\right)$ per cent air potato was superior in colour and appearance (18.40 out of 20) than plain burfi.

\section{Overall acceptability}

The overall acceptability of burfi was significantly affected by addition of potato flour. Burfi with treatment $\mathrm{T}_{3}$ (8.75) was significantly superior over the rest of the treatments. The lowest score obtained by burfi prepared with 20 per cent addition of potato flour $\left(\mathrm{T}_{5}\right)$. The present results study are in line with Datarkar (2012) and Adani (2011), they reported significant effect of addition of singhara flour $\left(\mathrm{T}_{2}\right) 5 \%$ and date paste $\left(\mathrm{T}_{4}\right) 4 \%$ respectively on the overall acceptability of burfi. 
Table.1 Effect of potato flour on sensory evaluation and overall acceptability of burfi

\begin{tabular}{|l|c|c|c|c|}
\hline $\begin{array}{c}\text { Treatments } \\
\text { Proportion } \\
(\text { CMIK:PF) }\end{array}$ & $\begin{array}{c}\text { Flavour } \\
(45)\end{array}$ & $\begin{array}{c}\text { Parameters } \\
\text { Body and } \\
\text { Texture }(35)\end{array}$ & $\begin{array}{c}\text { Colour and } \\
\text { Appearance } \\
(20)\end{array}$ & $\begin{array}{c}\text { Overall } \\
\text { acceptability }\end{array}$ \\
\hline $\mathrm{T}_{\mathbf{1}}(\mathbf{1 0 0 : 0 0 )}$ & $40.75^{\mathrm{b}}$ & $30.75^{\mathrm{b}}$ & $15.75^{\mathrm{b}}$ & $6.75^{\mathrm{b}}$ \\
\hline $\mathrm{T}_{2}(\mathbf{9 5 : 0 5})$ & $41.00^{\mathrm{b}}$ & $31.50^{\mathrm{b}}$ & $16.00^{\mathrm{b}}$ & $7.00^{\mathrm{b}}$ \\
\hline $\mathrm{T}_{3}(\mathbf{9 0 : 1 0})$ & $44.00^{\mathrm{a}}$ & $33.75^{\mathrm{a}}$ & $18.50^{\mathrm{a}}$ & $8.75^{\mathrm{a}}$ \\
\hline $\mathrm{T}_{4}(\mathbf{8 5 : 1 5})$ & $40.50^{\mathrm{b}}$ & $31.50^{\mathrm{b}}$ & $17.25^{\mathrm{ab}}$ & $7.25^{\mathrm{ab}}$ \\
\hline $\mathrm{T}_{5}(\mathbf{8 0}: 20)$ & $40.25^{\mathrm{b}}$ & $30.25^{\mathrm{b}}$ & $15.75^{\mathrm{b}}$ & $5.75^{\mathrm{b}}$ \\
\hline $\mathrm{SE}(\mathbf{m}) \pm$ & 0.639 & 0.487 & 0.566 & 0.532 \\
\hline $\mathrm{CD}$ at 5\% & 1.891 & 1.442 & 1.676 & 1.575 \\
\hline
\end{tabular}

(CMK-Cow Milk Khoa, PF-Potato Flour, * P $<0.05$ )

Table. 2 Cost configuration for one kg burfi prepared under various treatments

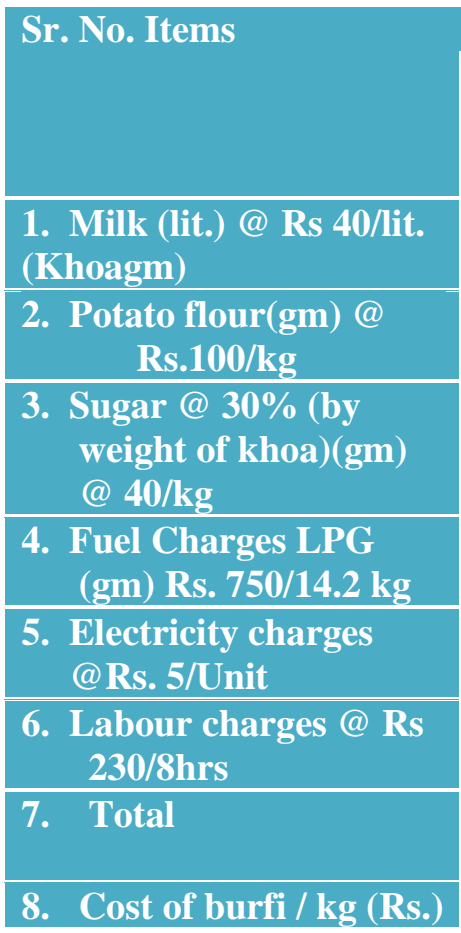

\begin{tabular}{|c|c|c|c|c|c|c|c|c|c|}
\hline \multicolumn{2}{|c|}{ T1 } & \multicolumn{2}{|c|}{ T2 } & \multicolumn{2}{|c|}{ T3 } & \multicolumn{2}{|c|}{ T4 } & \multicolumn{2}{|c|}{ T5 } \\
\hline Qty & $\begin{array}{c}\text { Value } \\
\text { (Rs) }\end{array}$ & Qty & $\begin{array}{c}\text { Value } \\
\text { (Rs) }\end{array}$ & Qty & $\begin{array}{c}\text { Value } \\
\text { (Rs) }\end{array}$ & Qty & $\begin{array}{c}\text { Value } \\
\text { (Rs) }\end{array}$ & Qty & $\begin{array}{c}\text { Value } \\
\text { (Rs) }\end{array}$ \\
\hline $\begin{array}{c}3.00 \\
(462)\end{array}$ & 120 & $\begin{array}{c}3.00 \\
(463)\end{array}$ & 120 & $\begin{array}{c}3.00 \\
(364)\end{array}$ & 120 & $\begin{array}{c}3.00 \\
(460)\end{array}$ & 120 & $\begin{array}{c}3.00 \\
(466)\end{array}$ & 120 \\
\hline - & - & 23.15 & 2.31 & 46.4 & 4.64 & 69 & 6.9 & 93.2 & 9.32 \\
\hline 138 & 5.52 & 138 & 5.52 & 138 & 5.52 & 138 & 5.52 & 138 & 5.52 \\
\hline 500 & 27.00 & 500 & 27.00 & 500 & 27.00 & 500 & 27.00 & 500 & 27.00 \\
\hline 0.40 & 2.00 & 0.40 & 2.00 & 0.40 & 2.00 & 0.40 & 2.00 & 0.40 & 2.00 \\
\hline 4 & 115 & 4 & 115 & 4 & 115 & 4 & 115 & 4.00 & 115 \\
\hline- & 269.52 & - & 272.83 & - & 273.98 & - & 276.42 & - & 278.84 \\
\hline- & 432.34 & - & 421.06 & - & 409.53 & - & 402.44 & - & 389.51 \\
\hline
\end{tabular}




\section{Flow chart for preparation of Burfi}

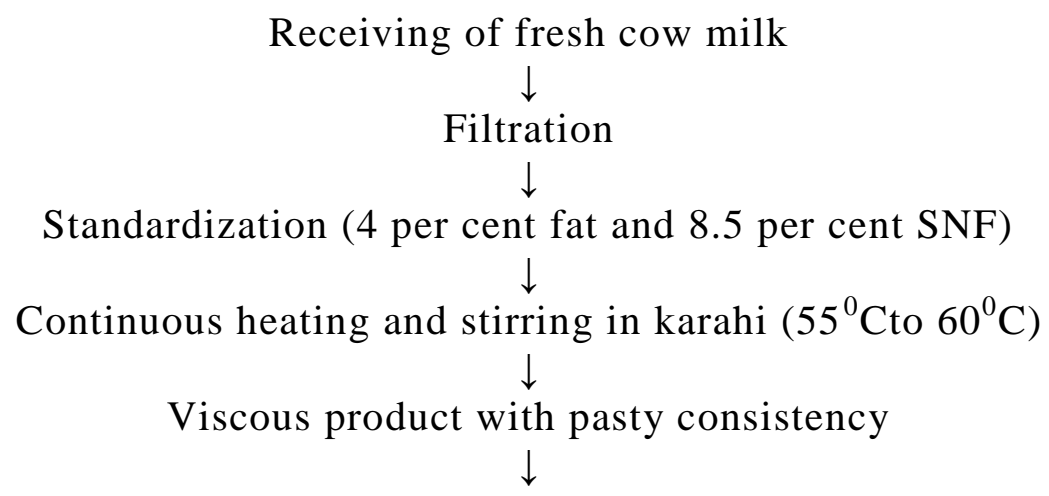

Addition of potato flour as per treatment and sugar $30 \%$ by weight of khoa
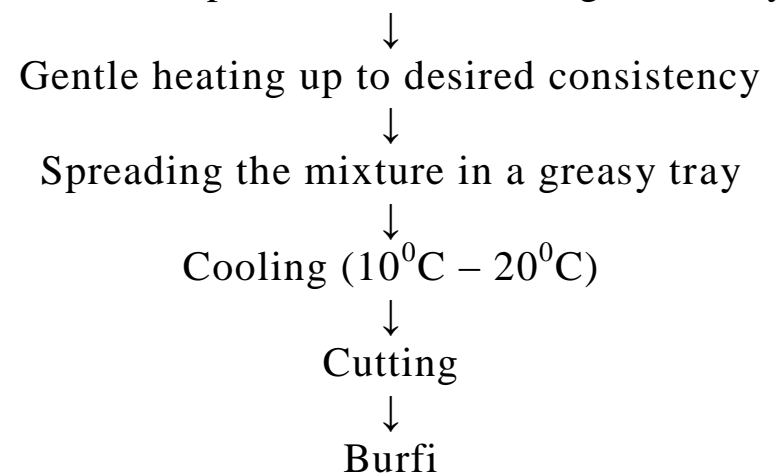

\section{Cost configuration of potato flour burfi}

The data on addition of potato flour extract in the cost configuration of potato flour burfi prepared under various treatments are presented in table 2 . The cost of production of one $\mathrm{kg}$ potato flour burfi was calculated by taking into consideration the prevailing retail market prices for the various items viz. milk, potato flour, sugar, while the other charges such as fuel and labour etc. worked out on the basis of actual hours of the work performed for the preparation of potato flour burfi. The data showed that cost of production of one $\mathrm{kg}$ potato flour burfi under various treatments ranged from 432.34 per $\mathrm{kg}\left(\mathrm{T}_{1} 100 \%\right.$ Cow milk khoa $+0 \%$ Potato flour) to 389.51 per kg $\left(\mathrm{T}_{5} 80 \%\right.$ Cow milk khoa $+20 \%$ Potato flour).

The cost of production of plain burfi was considerably higher than burfi blended with potato flour showed that the decreasing trend in cost of production of potato flour burfi. These differences were mainly because of variable levels of potato flour. A best treatment selected by judges was $\mathrm{T}_{3}(90 \%$ cow milk khoa $+10 \%$ potato flour) with cost 409.53 per $\mathrm{kg}$. The cost of burfi decreased with increase in level of potato flour.

More or less similar results were reported by Bhosale (2017) observed that the cost of production was higher of treatment $\mathrm{T}_{1}$ with 0 parts of bottle gourd level (Rs.354.02 per kg) while the burfi prepared by blending with 15 parts of bottle gourd level ( $\mathrm{T}_{4}$ treatment) costing (Rs.312.48 per $\mathrm{kg}$ ) which was superiorly accepted by panel of judges.

It may be inferred that the superior, nutritional and medicinal quality potato burfi can be prepared by addition of 10 parts of potato flour and 90 parts of cow milk khoa with 30 per cent sugar. (Costing Rs.409.53) 


\section{References}

Adani, R. (2011) Utilization of date in the preparation of cow milk burfi. M.Sc. thesis (unpub.) Dr. P.D.K.V., Akola.

Anonymous, 2015. Milk production of India. (Annual report of NDDB 2014-2015).

Anonymous, 2017. Milk production of India. (Annual report of NDDB 2016- 2017).

Bhosale Suchita. 2017. Studies on Utilization of bottle gourd (Lagenaria siceraria) pulp in preparation of cow milk burfi. M.Sc. Thesis (unpub.) Dr. P.D.K.V., Akola.

Chandrasekara, A. and T. J. Kumar, 2016. Roots and tubers crops as functional foods: A review on phytochemical constituents and their potential health benefits. International Journal of Food science, Vol. 2016, Article ID 3631647.

Datarkar, K. 2012. Utilization of singhara flour in preparation of cow milk burfi.
M. Sc. Thesis (unpub.) Dr. P.D.K.V., Akola.

Kaur, A. and Anita Kochhar, 2014. Sensory and nutritional evaluation of value added products using potato flour for nutritional and health benefits. International journal of medical sciences, Volume 7; 1-6.

Meshram, P. M. 2014. Utilization of air potato (Dioscorea bulbifera) flour for preparation of burfi. M.Sc. Thesis (unpub). Dr. P. D. K. V., Akola.

Nelson, J.A. and G.M. Trout, 1964. Judging dairy products. 4th edition. The Olesen Publishing Co. Milwankee Official Methods of Analysis Chemists, Washington.

Pal, D. and S.K. Gupta, 1985. Sensory evaluation of Indian milk products. Indian Dairyman, 37(10): 465-467.

Snedecor, G. W. and W. G Cochran, (1994) Statistical methods, 8th edition, Oxford and IBA publishing company, Calcutta.

\section{How to cite this article:}

Ramteke, V.M., V.G. Atkare and Khupse, S.M. 2018. Studies on Preparation, Sensory Evaluation and Cost Configuration of Potato (Solanum tuberosum) Flour Burfi. Int.J.Curr.Microbiol.App.Sci. 7(08): 1610-1615. doi: https://doi.org/10.20546/ijcmas.2018.708.184 